\title{
Chemical and Chemotaxonomical Studies of Ferns. XXXI.1) Chemical Studies on the Constituents of Arachinoides standishii $\mathrm{OHWI}^{2)}$
}

\author{
Nobutoshi Tanaka, Haruka Maehashi, Sumie Saito, Takao Murakami, ${ }^{3 a}$ \\ Yasuhisa Saiki, ${ }^{3 b)}$ ChiU-Ming $\mathrm{Chen}^{3 c)}$ and Yoichi Iitaka ${ }^{3 d)}$ \\ Faculty of Pharmaceutical Sciences, Science University of Tokyo, $\left.{ }^{3 a}\right)$ Department of \\ Pharmaceutical Sciences, Kobe Gakuin University, ${ }^{3 b)}$ Department of \\ Chemistry, National Ising Hua University ${ }^{3}$ ) and Faculty of \\ Pharmaceutical Sciences, University of Tokyo $\left.{ }^{3 d}\right)$
}

(Received May 29, 1980)

\begin{abstract}
Six new compounds were isolated from the methanol extract of Arachinoides standishii Orwi. Chemical and physicochemical studies showed their structures to be 1-(2,4,6trimethoxyphenyl)-but-trans-2-en-1-one (I), 5,7-dimethoxy-2-methylchromanone (II), 2ethyl-5,7-dimethoxychromanone (III), 5-hydroxy-dimethoxy-2-methyl-chromanone (IV), 3- $\beta$-D-allosyloxy-1-(2-hydroxy-4,6-dimethoxyphenyl)-butan-1-one (V) and 8-carboxy-6hydroxy-2,5-dimethyl-2a,3,4,5-tetrahydroacenaphthene (VI). Compound VI, named ryomenin, is the first sesquiterpene reported to possess a tetrahydroacenaphthene skeleton.

Keywords_-Avachinoides standishii; Aspidiaceae; 1-phenylbutan-1-one derivatives; 1-phenylbut-trans-2-en-1-one derivatives; $\mathrm{D}$-alloside; chromanones; tetrahydroacenaphthene derivatives; sesquiterpene; $\mathrm{X}$-ray analysis
\end{abstract}

This paper deals with the structure elucidation of six new compounds, tentatively named compounds I, II, III, IV, V and VI, isolated from the fronds of Arachinoides standishii $\mathrm{OHwI}_{\mathrm{H}}$ ("Ryomenshida" in Japanese, Aspidiaceae). The isolation procedure is shown in Chart 1 and described in the experimental section.

Compound I, $\mathrm{C}_{13} \mathrm{H}_{1.6} \mathrm{O}_{4}\left(\mathrm{M}^{+} 236.1065\right)$, colorless plates, $\mathrm{mp} 84-89^{\circ}$, showed ultraviolet (UV) absorption, $\lambda_{\max }^{\text {Meor }}(\log \varepsilon) 224(4.29)$ and $302(3.49) \mathrm{nm}$, and the infrared (IR) spectrum showed $\nu_{\max }^{\mathrm{KBr}} \mathrm{cm}^{-1} 1645$ ( $\alpha \beta, \alpha^{\prime} \beta^{\prime}$-unsaturated ketone), 1605 and 970 (trans-di-substituted double bond), 1587 and 1497 (benzene ring), suggesting the presence of a phenyl alkenyl ketone moiety. The proton nuclear magnetic resonance (PMR) spectrum (in $\mathrm{CDCl}_{3}$ ) showed aromatic methoxy proton signals at $\delta 3.63(6 \mathrm{H}, \mathrm{s})$ and $3.70(3 \mathrm{H}, \mathrm{s})$ and the signal of two aromatic protons at $5.99(2 \mathrm{H}, \mathrm{s})$. The presence of two equivalent aromatic methoxy groups and two equivalent aromatic protons indicated that the benzene ring is substituted symmetrically. The aromatic proton signals usually appear in the range of $6.0-6.5 \mathrm{ppm}$ in 2,4,6-oxygenated phenyl groups and at $6.5-7.5 \mathrm{ppm}$ in 3,4,5-oxygenated phenyl groups. ${ }^{4)}$ In compound I, it appeared at higher field, so it was concluded that the benzene ring is substituted by three methoxy groups at C-2, C-4 and C-6. The PMR spectrum also exhibited a vinyl methyl signal at $\delta 1.78(3 \mathrm{H}, \mathrm{d}$, $J=6 \mathrm{~Hz})$ and two olefinic proton signals at $6.13(1 \mathrm{H}, \mathrm{d}, J=16 \mathrm{~Hz})$ and $6.54(1 \mathrm{H}, \mathrm{d}$ of $\mathrm{q}, J=16$ and $6 \mathrm{~Hz}$ ), indicating the presence of a trans-propenyl group. On the basis of these spectral data, it was concluded that compound I should be 1-(2,4,6-trimethoxyphenyl)-but-trans-2-

1) Part XXX: N. Tanaka, S. Nagase, K. Wachi, T. Murakami, Y. Saiki, and C.-M. Chen, Chem. Pharm. Bull., 28, 2843 (1980).

2) Preliminary communication: N. Tanaka, H. Maehashi, S. Saito, T. Murakami, Y. Saiki, C.-M. Chen, and Y. Iitaka, Chem. Pharm. Bull., 27, 2874, (1979).

3) Location: a) Funakawara-machi, Shinjuku-ku, Tokyo, 162, Japan; b) Arise, Igawatani-machi, Tarumi-ku, Kobe, 673, Japan; c) Kuang Fu Road, Hsinchu, Taiwan, China; d) Hongo, Tokyo, 113, Japan.

4) T.J. Mabry, K.R. Markham, and M.B. Thomas, "The Systematic Identification of Flavonoids," SpringerVerlag, Berlin, Heiderberg, New York, 1970. 


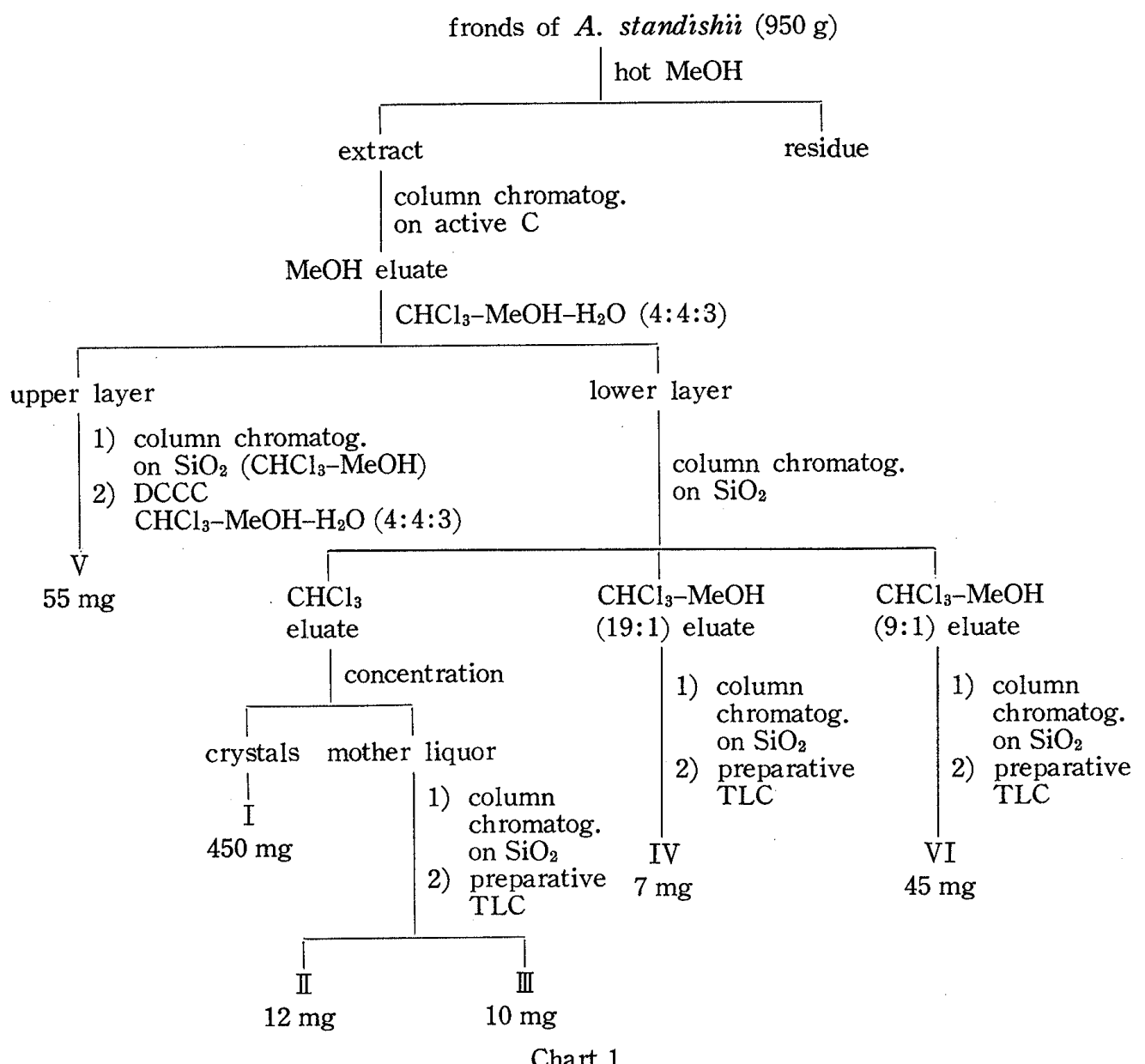

en-l-one (I). The ${ }^{13} \mathrm{C}$-nuclear magnetic resonance (CMR) data (Fig. 1, $/ \mathrm{ppm}$, in $\mathrm{CDCl}_{3}$ ) and mass spectral (MS) data, base peak at $m / z$ 195, supported this conclusion.

Compound II, $\mathrm{C}_{12} \mathrm{H}_{14} \mathrm{O}_{4}\left(\mathrm{M}^{+} 222.0890\right)$, colorless needles, mp 77-79 ${ }^{\circ}$, showed IR absorption at 1665 and $1600 \mathrm{~cm}^{-1}$ (in $\mathrm{KBr}$ ), suggesting the presence of an aryl ketone. In the PMR spectrum (in $\left.\mathrm{CDCl}_{3}\right)$, two aromatic methoxy signals appeared at $\delta 3.74(3 \mathrm{H}, \mathrm{s})$ and $3.80(3 \mathrm{H}, \mathrm{s})$ and the signal of two aromatic protons $(5.98,2 \mathrm{H}, \mathrm{s})$, as in the case of compound I, indicated that the benzene ring is oxygenated at $\mathrm{C}-2, \mathrm{C}-4$ and $\mathrm{C}-6$.

The PMR spectrum also exhibited a methyl signal at $1.40(3 \mathrm{H}, \mathrm{d}, J=7 \mathrm{~Hz})$, the signal of a methylene adjacent to ketone at $2.53(2 \mathrm{H}, \mathrm{d}, J=7 \mathrm{~Hz})$ and the signal of a proton attached to carbon bearing an oxygen function at $4.45(1 \mathrm{H}$, sextet, $J=7 \mathrm{~Hz})$. In a nuclear magnetic double resonance experiment on compound II, two doublet signals at $\delta 1.40$ and 2.53 changed into two broad singlet signals on irradiation at $\delta 4.45$. This elucidated the partial structure $\mathrm{CH}_{3}-\mathrm{CH}(\mathrm{OR})-\mathrm{CH}_{2}-\mathrm{CO}-$. The combination of this with the benzene ring led to the structure 5,7-dimethoxy-2-methylchromanone (II). The absorption maximum at $283 \mathrm{~nm}(\log \varepsilon 4.31$, in $\mathrm{MeOH}$ ) in the UV spectrum, which is characteristic of 5,7-dimethoxychromanone, ${ }^{5)}$ and the base peak at $m / z 180$ in the MS supported this structure.

Compound III, $\mathrm{C}_{13} \mathrm{H}_{16} \mathrm{O}_{4}\left(\mathrm{M}^{+} 236.1046\right)$, afforded colorless needles from $n$-hexane-benzene, $\operatorname{mp} 200-202^{\circ}$. The IR $\left(\nu_{\max }^{\mathrm{KBr}} 1670,1605 \mathrm{~cm}^{-1}\right)$, UV $\left(\lambda_{\max }^{\mathrm{MeOH}} 284 \mathrm{~nm}, \log \varepsilon 4.41\right)$ and PMR $\left[\delta_{\mathrm{CDCl}}\right.$, $3.82(3 \mathrm{H}, \mathrm{s}), 3.87(3 \mathrm{H}, \mathrm{s}), 6.06(2 \mathrm{H}, \mathrm{s})]$ spectra were similar to those of compound II, indicating that compound III has a 5,7-dimethoxychromanone skeletone. The PMR spectrum also exhibited signals due to an ethyl group at $\delta 1.04(3 \mathrm{H}, \mathrm{t}, J=7 \mathrm{~Hz})$ and $1.80(2 \mathrm{H}$, quintet, $J=7$

5) B.S. Joshi and K.R. Ravindranath, J. Chem. Soc., Perkin I, 1977, 433. 
$\mathrm{Hz})$, a methylene signal at $2.60(2 \mathrm{H}, \mathrm{d}, J=7 \mathrm{~Hz})$ and a methine signal at $4.31(1 \mathrm{H}$, quintet, $J=7 \mathrm{~Hz}$ ). On irradiation at $\delta 4.31$, a quintet signal at 1.80 and a doublet signal at 2.60 changed to a quartet and a singlet, respectively. These data indicated compound III to be 2-ethyl-5,7dimethoxychromanone (III). The MS data $\left[m / z 207\left(\mathrm{M}^{+}-\mathrm{C}_{2} \mathrm{H}_{5}\right), 180\right.$ (base peak)] supported this structure.

Compound IV, $\mathrm{C}_{12} \mathrm{H}_{14} \mathrm{O}_{5}\left(\mathrm{M}^{+} 238.0841\right)$, colorless needles, $\mathrm{mp} 83-86^{\circ}$, showed UV absorp. tion maxima (in $\mathrm{MeOH}$ ) at $212(\log \varepsilon 4.29), 245$ (4.09), 288 (4.16) and 349 (3.68) nm. The IR $\left[v_{\max }^{\mathrm{KBr}} \mathrm{cm}^{-1} 3200(\mathrm{OH}), 1650(\mathrm{C}=\mathrm{O}), 1600\right.$ (benzene ring)] and PMR [ $\delta_{\mathrm{CDCl}_{\mathrm{s}}} 1.34(3 \mathrm{H}, \mathrm{d}, J=7$ $\mathrm{Hz}), 2.48(2 \mathrm{H}, \mathrm{d}, J=7 \mathrm{~Hz}), 3.73(3 \mathrm{H}, \mathrm{s}), 3.81(3 \mathrm{H}, \mathrm{s}), 4.49(1 \mathrm{H}$, sextet, $J=7 \mathrm{~Hz}), 6.06(1 \mathrm{H}, \mathrm{s})]$ spectra and MS $\left[m / z 238\left(\mathrm{M}^{+}\right), 223\left(\mathrm{M}^{+}-\mathrm{CH}_{3}\right), 196\right.$ (base peak)] indicated compound IV to be 2-methylchromanone substituted by a hydroxyl and two methoxyl groups on the benzene ring. In the IR spectrum, the absorption due to the carbonyl group $\left(1650 \mathrm{~cm}^{-1}\right)$ appeared at lower wave number than those of compound II and III (1665 and $\left.1670 \mathrm{~cm}^{-1}\right)$. On the other hand, the methyl ether of compound IV, (VII), showed an IR absorption maximum at $1675 \mathrm{~cm}^{-1}$ assignable to the carbonyl group. These spectral data suggested that the hydro$\mathrm{xyl}$ group of compound IV is located at C-5, forming a strong hydrogen bond with the carbonyl group at C-4. Thus, the structure was established to be 5-hydroxy-dimethoxy-2-methylchromanone (IV). However, the positions of the methoxy groups on the benzene ring could not be determined.

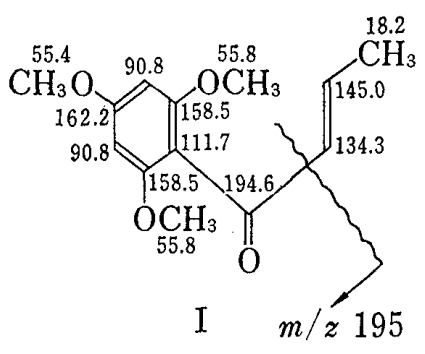<smiles>[R10]Oc1cc(OC)cc(OC)c1C(=O)CC(C)O[R20]</smiles>

$\mathrm{V}: \mathrm{R}_{1}=\mathrm{H}, \mathrm{R}_{2}=\beta$-D-allosyl

VIII $: \mathrm{R}_{1}=\mathrm{R}_{2}=\mathrm{H}$

IX: $\mathrm{R}_{1}=\mathrm{CH}_{3}, \mathrm{R}_{2}=\mathrm{H}$

XIV : $\mathrm{R}_{1}=\mathrm{R}_{2}=\mathrm{CH}_{3}$

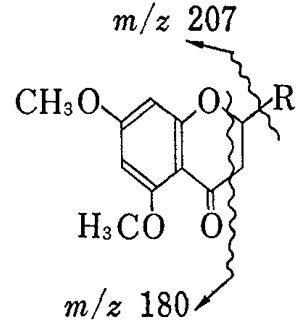

II $: \mathrm{R}=\mathrm{CH}_{3}$

III $: \mathrm{R}=\mathrm{CH}_{2} \mathrm{CH}_{3}$<smiles>[R]OC(=O)c1cc(O)c2c3c1CC(C)C3CCC2C</smiles>

$\mathrm{VI}: \mathrm{R}=\mathrm{H}$

$\mathrm{XIII}: \mathrm{R}=\mathrm{CH}_{3}$

Fig. 1

Compound $\mathrm{V}$, a colorless amorphous powder, $[\alpha]_{\mathrm{D}}^{25}-25^{\circ}(c=2.8, \mathrm{MeOH})$, showed IR absorption maxima (in $\mathrm{KBr}$ ) at $3400(\mathrm{OH}), 1620(\mathrm{C}=\mathrm{O})$ and 1590 (benzene ring) $\mathrm{cm}^{-1}$. The strong absorption band at $3400 \mathrm{~cm}^{-1}$ in the IR spectrum and the positive anthrone test suggested the presence of a glycosyloxy moiety in compound V. The PMR spectrum (in pyridine$\left.d_{5}\right)$ exhibited a methyl signal at $\delta 1.44(3 \mathrm{H}, \mathrm{d}, J=7 \mathrm{~Hz})$, a proton signal at $3.07(1 \mathrm{H}$, $\mathrm{d}$ of $\mathrm{d}$, $J=16$ and $7 \mathrm{~Hz}$ ) which was assignable to one proton of a methylene group, a two methoxy signal at $3.70(6 \mathrm{H}, \mathrm{s})$, an anomeric proton signal at $5.39(1 \mathrm{H}, \mathrm{d}, J=7 \mathrm{~Hz})$, two aromatic proton signals at $5.99(1 \mathrm{H}, \mathrm{d}, J=2 \mathrm{~Hz}$, meta coupling) and $6.23(1 \mathrm{H}, \mathrm{d}, J=2 \mathrm{~Hz}$, meta coupling) and complicated signals of eight protons from 3.5 to 5.0. On irradiation at $\delta 4.65$, a double doublet 
at 3.07 and a doublet at 1.44 changed to a doublet $(J=16 \mathrm{~Hz})$ and a singlet, respectively. This experiment provided the partial structure $\mathrm{CH}_{3}-\mathrm{CH}(\mathrm{OR})-\mathrm{CH}_{2}-\mathrm{CO}-$.

On acid hydrolysis, compound $\mathrm{V}$ gave $\mathrm{D}$-allose, 5,7-dimethoxy-2-methylchromanone (II) and minor products derived from the aglycone. As compound II has no hydroxyl group to link with D-allose, it was considered to be derived from the aglycone of compound $\mathrm{V}$ under acidic conditions. It is reasonable to assume that the aglycone of compound $\mathrm{V}$ is 3 -hydroxy1-(2-hydroxy-4,6-dimethoxyphenyl)-butan-1-one (VIII) and that compound II was derived from it through the mechanism shown in Fig. 2, XI to XII. The PMR spectrum and MS [m/z 240 (aglycone), 181 (base peak)] data supported this view. Thus, compound V was concluded to be the D-alloside of compound VIII.

Compound V showed a UV absorption maximum at $291 \mathrm{~nm}(\log \varepsilon 4.28$, in $\mathrm{MeOH})$, and a bathochromic shift of about $20 \mathrm{~nm}$ was observed on addition of $\mathrm{AlCl}_{3}$. On the other hand, 3-hydroxy-1-(2,4,6-trimethoxyphenyl)-butan-1-one (IX), which was obtained on hydration of compound I, showed a UV absorption maximum at $276 \mathrm{~nm}$, and this was unaffected by the addition of $\mathrm{AlCl}_{3}$. These results and the absorption band due to a chelated carbonyl group $\left(\nu_{\max }^{\mathrm{KBr}} 1620 \mathrm{~cm}^{-1}\right)$ in the IR spectrum indicated that the aryl ketone is chelated with the phenolic hydroxyl group. Therefore the location of the D-allosyloxy moiety in compound $\mathrm{V}$ was determined to be at $\mathrm{C}-3$. As the anomeric proton signal of the D-allosyloxy moiety was observed as a doublet with $J=7 \mathrm{~Hz}$ in the PMR spectrum, D-allose is $\beta$-linked to compound VIII. Consequently, the structure of compound V was characterized as $3-\beta$-D-allosyloxy-1(2-hydroxy-4,6-dimethoxyphenyl)-butan-1-one (V).

Though compounds II, III and IV have chiral centers (C-2), they showed no optical rotation, indicating them to be racemates. Thus, they are probably artifacts derived from natural products such as X and XI. However, such compounds as X and XI were not found in the methanol extracts of this fern.<smiles>COc1cc(OC)c(C(=O)C(C)(CC(C)C)CC(C)OC(C)C)c(OC)c1</smiles>

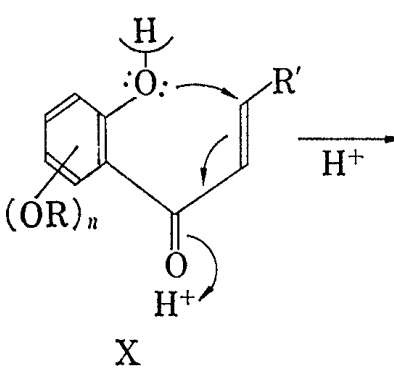<smiles>[R20]c1cccc2c1C(=O)CC([R])O2</smiles><smiles>C[InH]</smiles>

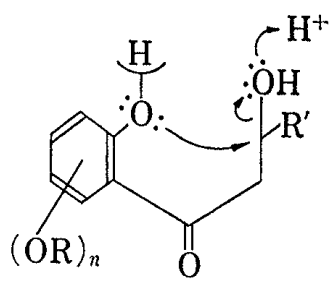

$\mathrm{XI}$

Fig. 2

Compound VI, $\mathrm{C}_{15} \mathrm{H}_{18} \mathrm{O}_{3}\left(\mathrm{M}^{+} 246.1263\right)$, colorless needles, mp $204-207^{\circ},[\alpha]_{\mathrm{D}}^{25}-214^{\circ}(c=$ $0.14, \mathrm{MeOH})$, named ryomenin, showed IR $\left[\nu_{\max }^{\mathrm{KBr}} \mathrm{cm}^{-1} 3500(\mathrm{OH}), 1675(\mathrm{COOH}), 1610\right.$ (benzene ring)] and UV [ $\lambda_{\max }^{\text {Meor }} \mathrm{nm}(\log \varepsilon) 211$ (4.51), 252 (3.98), 310 (3.58)] absorptions. The PMR spectrum (in pyridine- $d_{5}$ ) exhibited two secondary methyl signals at $\delta 1.23(3 \mathrm{H}, \mathrm{d}, J=7 \mathrm{~Hz})$ and $1.68(3 \mathrm{H}, \mathrm{d}, J=7 \mathrm{~Hz})$, an aromatic proton signal at $8.07(1 \mathrm{H}, \mathrm{s})$ and a carboxyl proton 
signal at $10.74\left(1 \mathrm{H}\right.$, broad s). The CMR spectrum (in pyridine- $d_{5}$ ) showed eight $s p^{3}$ carbon signals at $\delta 18.0(\mathrm{q}), 21.5(\mathrm{q}), 28.5(\mathrm{t}), 29.7(\mathrm{~d}), 34.1(\mathrm{t}), 41.8(\mathrm{t}), 44.7(\mathrm{~d})$ and $49.7(\mathrm{~d})$ and seven $s p^{2}$ carbon signals at $\delta 115.2(\mathrm{~d}), 126.0(\mathrm{~s}), 131.4(\mathrm{~s}), 135.9(\mathrm{~s}), 148.0(\mathrm{~s}), 155.3(\mathrm{~s})$ and 169.8 (s). These spectral data suggested that ryomenin (VI) is a tricyclic compound containing a pentasubstituted benzene ring, an aromatic carboxylic acid, a phenolic hydroxyl group and two secondary methyl groups.

Further structural elucidation of ryomenin (VI), including the relative stereochemistry, was accomplished by X-ray diffraction analysis of its methyl ester (XIII), mp 163-165 $[\alpha]_{\mathrm{D}}^{25}-198^{\circ}(c=0.28, \mathrm{MeOH})$.

The crystals were grown from a methanol solution as prisms. The cell parameters and intensity data were measured on a Philips PW 1100 diffractometer using $\mathrm{Cu} K \alpha$ radiation monochromated by means of a graphite plate. The crystal data are given in Table I.

TABle I. Crystal Data

Ryomenin methyl ester, $\mathrm{C}_{16} \mathrm{H}_{20} \mathrm{O}_{3}$, MW 260.3

Orthorhombic, space group $P 2_{1} 2_{1} 2_{1}, Z=4, D x=1.227 \mathrm{~g} \mathrm{~cm}^{-1}$

$a=9.145(5), b=18.335(10), c=8.403(5) \AA, V=1409.0 \AA^{3}$

Intensities were measured by a $\theta-2 \theta$ scan method with a scan speed of $4^{\circ} \sec ^{-1}$ in $\theta$. The scans were repeated twice when the total counts in a single scan were less than 3000 . The background was measured at both ends of the scan for half the total scan time. In all, 1506 reflections were measured above the $2 \sigma$ (I) level within a $2 \theta$ angle of $156^{\circ}$. The crystal structure was solved by the direct method using MULTAN ${ }^{6}$ ) and was refined by the block-diagonal least-squares method. The final $R$ value was 0.08 for 1506 reflections without hydrogen atoms. Unit weight was assigned for each reflection. The atomic parameters are listed in Table II.

TABle II. Final Atomic Parameters $\left(\times 10^{4}\right)$

\begin{tabular}{|c|c|c|c|c|c|c|c|c|c|}
\hline Atom & $x$ & $y$ & $z$ & $\beta_{11}$ & $\beta_{22}$ & $\beta_{33}$ & $\beta_{12}$ & $\beta_{13}$ & $\beta_{23}$ \\
\hline$C(1)$ & $1022(4)$ & $3392(2)$ & $468(4)$ & $113(4)$ & $23(1)$ & $113(5)$ & $0(2)$ & $4(5)$ & $-6(2)$ \\
\hline $\mathrm{C}(2)$ & $1003(5)$ & $3041(2)$ & $1955(5)$ & $134(5)$ & $23(1)$ & $128(6)$ & $-5(2)$ & $11(5)$ & $1(2)$ \\
\hline$C(3)$ & $2177(5)$ & $3092(2)$ & $2997(5)$ & $145(5)$ & $25(1)$ & $105(5)$ & $-3(2)$ & $10(5)$ & $2(2)$ \\
\hline$C(4)$ & $3416(4)$ & $3500(2)$ & $2592(5)$ & $122(4)$ & $29(1)$ & $96(5)$ & $8(2)$ & $-2(4)$ & $2(2)$ \\
\hline$C(5)$ & $3456(4)$ & $3870(2)$ & $1132(4)$ & $105(4)$ & $22(1)$ & $101(5)$ & $6(1)$ & $4(4)$ & $1(2)$ \\
\hline$C(6)$ & $2253(4)$ & $3813(2)$ & $132(4)$ & $104(3)$ & $24(1)$ & $86(5)$ & $7(2)$ & $5(4)$ & $3(2)$ \\
\hline$C(7)$ & $2514(4)$ & $4195(2)$ & $-1429(4)$ & $129(5)$ & $27(1)$ & $95(5)$ & $11(2)$ & $1(4)$ & $9(2)$ \\
\hline$C(8)$ & $1785(5)$ & $3767(3)$ & $-2771(5)$ & $139(5)$ & $44(1)$ & $101(6)$ & $1(2)$ & $-11(5)$ & $2(3)$ \\
\hline C (9) & $147(5)$ & $3684(3)$ & $-2356(6)$ & $126(5)$ & $53(2)$ & $132(6)$ & $8(3)$ & $-21(5)$ & $14(3)$ \\
\hline$C(10)$ & $-177(5)$ & $3291(2)$ & $-770(5)$ & $130(4)$ & $33(1)$ & $139(6)$ & $-7(2)$ & $-21(5)$ & $-11(2)$ \\
\hline$C(11)$ & $4212(4)$ & $4261(2)$ & $-1467(4)$ & $120(4)$ & $28(1)$ & $101(5)$ & $5(2)$ & $16(4)$ & $8(2)$ \\
\hline$C(12)$ & $4635(4)$ & $4317(2)$ & $322(5)$ & $112(4)$ & $33(1)$ & $121(5)$ & $-2(2)$ & $4(5)$ & $18(2)$ \\
\hline $\mathrm{C}(13)$ & $4761(6)$ & $4896(2)$ & $-2464(6)$ & $169(6)$ & $35(1)$ & $178(7)$ & $-5(3)$ & $25(7)$ & $28(3)$ \\
\hline $\mathrm{C}(14)$ & $4678(5)$ & $3470(2)$ & $3715(5)$ & $137(5)$ & $36(1)$ & $110(5)$ & $13(2)$ & $-3(5)$ & $6(2)$ \\
\hline$C(15)$ & $-1705(5)$ & $3521(3)$ & $-177(8)$ & $109(5)$ & $63(2)$ & $205(9)$ & $-6(3)$ & $-11(6)$ & $-3(4)$ \\
\hline$C(16)$ & $7019(6)$ & $3871(5)$ & $4422(8)$ & $140(6)$ & $94(4)$ & $213(12)$ & $-22(4)$ & $-79(8)$ & $21(6)$ \\
\hline$O(1)$ & $-201(4)$ & $2625(2)$ & $2306(4)$ & $166(4)$ & $37(1)$ & $183(5)$ & $-28(2)$ & $5(5)$ & $15(2)$ \\
\hline $\mathrm{O}(2)$ & $4753(4)$ & $3016(2)$ & $4772(4)$ & $186(5)$ & $54(1)$ & $163(5)$ & $7(2)$ & $-41(5)$ & $38(2)$ \\
\hline$O(3)$ & $5714(4)$ & $3955(2)$ & $3444(4)$ & $154(4)$ & $55(1)$ & $171(5)$ & $-15(2)$ & $-53(5)$ & $17(2)$ \\
\hline
\end{tabular}

The temperature factors are: $T=\exp \left[-\left(\beta_{11} h^{2}+\beta_{22} k^{2}+\beta_{38} l^{2}+2 \beta_{12} h k+2 \beta_{13} h l+2 \beta_{23} k l\right)\right]$.

6) G. Germain, P. Main, and M.M. Woolfson, Acta Cryst., A27, 368 (1971). 


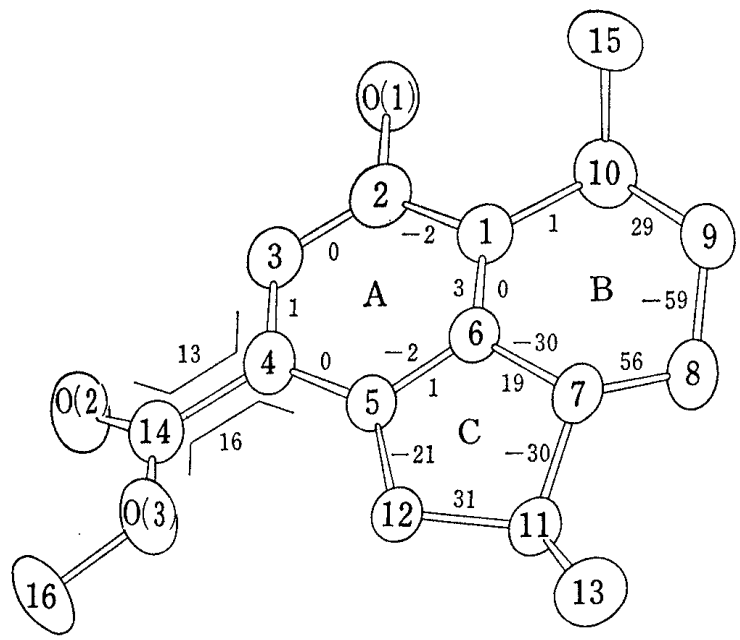

Fig. 3

The chemical structure was confirmed as shown in Fig. 1 [XIII]. ${ }^{7)}$ As the absolute configuration of XIII were not determined in this experiment, the antipodal structure is also assignable for XIII.

Fig. 3 is a perspective drawing of the molecular structure, illustrating the conformation of the molecule. The endo-cyclic torsion angles are also given in Fig. $3 . \quad$ It is clear that ring $\mathrm{A}$ is nearly planar, while $\mathrm{B}$ adopts a half-chair conformation with a flagpole at $\mathrm{C}(8)$. The five-membered ring $\mathrm{C}$ takes an envelope form with a flap at $\mathrm{C}$ (11). The methoxycarbonyl group is not co-planar with the A ring, but is twisted slightly by an angle of $15^{\circ}$.

The bond lengths and angles are normal, as shown in Fig. 4. Their standard deviations were estimated as $\sigma(\mathrm{C}-\mathrm{C})=0.006 \AA, \sigma(\mathrm{C}-\mathrm{C}-\mathrm{C})=0.3^{\circ}$. There is only one kind of hydrogen bond in the crystal structure, which binds $0(1) \mathrm{H}$ to $0(2)$ with a distance of $2.722 \AA$.

Thus, the structure of XIII, except for the absolute configuration, was determined unequivocally. Therefore, the structure [VI] in Fig. 1 or its antipode was assigned for ryomenin. Ryomenin is a novel type of sesquiterpene possessing a tetrahydroacenaphthene skeleton.

\section{Experimental}

Melting points were determined with a Yanagimoto micromelting point apparatus and are uncorrected. Optical rotations were taken with a JASCO DIP-SL automatic polarimeter. Gas-liquid chromatography (GLC) was run on a Shimadzu GC-4BM-PF gas chromatograph with a flame ionization detector using a glass column $(2 \mathrm{~m} \times 2.6 \mathrm{~mm}$ I.D.) packed with $1.5 \% \mathrm{SE}-30$ on Chromosorb W. The PMR spectra were measured at $60 \mathrm{MHz}$ with a Hitachi R24B spectrometer and at $100 \mathrm{MHz}$ with a JEOL FX-100 spectrometer, using tetramethylsilane as an internal standard (s, singlet; $d$, doublet; $t$, triplet). MS were taken at $70 \mathrm{eV}$ on a Hitachi RMU-7M mass spectrometer with a direct inlet system. UV spectra were recorded on a Hitachi 323 spectrometer and IR spectra on a Hitachi IR-215 spectrometer. CMR spectra were measured at $25 \mathrm{MHz}$ with a

7) In the preliminary communication, ${ }^{2)}$ the angular hydrogen bond was erroneously drawn as $\alpha$. It should be $\beta$. 
JEOL FX-100 spectrometer with ${ }^{2} \mathrm{H}$ internal lock, using tetramethylsilane as an internal standard. The droplet countercurrent chromatography (DCCC) apparatus consists of 200 column units of glass tubing (2.4 $\mathrm{mm}$ I.D., $60 \mathrm{~cm}$ long) connected by Teflon tubing $\left(0.5 \mathrm{~mm} \mathrm{I.D.)}\right.$. The solvent system used was $\mathrm{CHCl}_{3}-\mathrm{MeOH}_{-}$ $\mathrm{H}_{2} \mathrm{O}(4: 4: 3)$, with the upper layer as the mobile and the lower layer as the stationary phase. The flow rate was $20 \mathrm{ml} / \mathrm{h}$ and fractions of $5 \mathrm{ml}$ were taken in a fraction collector. Active carbon for column chromatography (Wako Pure Chemical) and silica gel (above 100 mesh, Kanto Chemical) were used for column chromatography. Silica gel G (Merck, type 60) and silica gel $\mathrm{GF}_{254}$ (Merck, type 60) were used for preparative thin-layer chromatography (preparative TLC).

Isolation of Compounds I, II, III, IV, V and VI_— The air-dried fronds (950 g) of Arachinoides standishii OHwr collected in September at in Mt. Mitsuishi, Chiba prefecture, were extracted with methanol (3l×3) under reflux. The combined extracts $(91)$ and then fresh methanol $(101)$ were passed over active carbon $(100 \mathrm{~g})$ packed in a column of $7 \mathrm{~cm}$ diameter. The resulting solution (19 1) was concentrated to a syrup under reduced pressure. The syrup was distributed between the upper and lower layers of a mixture of $\mathrm{CHCl}_{3}(200 \mathrm{ml})$, methanol $(200 \mathrm{ml})$ and water $(150 \mathrm{ml})$.

The lower layer was concentrated under reduced pressure to give a syrup, which was chromatographed on a silica gel column $(150 \mathrm{~g})$ using $\mathrm{CHCl}_{3}\left(400 \mathrm{ml}\right.$, Frac. 1), $5 \%$ methanol in $\mathrm{CHCl}_{3}\left(600 \mathrm{ml}, \mathrm{Frac}_{2}\right)$ and $10 \%$ methanol in $\mathrm{CHCl}_{3}(200 \mathrm{ml}$, Frac. 3$)$ as eluents. Frac. 1 was concentrated to yield a crystalline substance, which was collected by filtration and recrystallized from ethanol to afford compound I (450 $\mathrm{mg})$. The filtrate was rechromatographed on the silica gel column using benzene and $\mathrm{CHCl}_{3}$ as eluents to yield a mixture of compounds II and III. The mixture was subjected to preparative TLC (solvent system, $\mathrm{CHCl}_{3}:$ ether $=$ $2: 1)$ to yield pure compounds II $(12 \mathrm{mg})$ and III $(10 \mathrm{mg})$. Frac. 2 was rechromatographed on a silica gel column (eluted with $\mathrm{CHCl}_{3}$ and ether) followed by preparative TLC (solvent system, $\mathrm{CHCl}_{3}:$ ether $=2: 1$ ) to yield compound IV $\left(7 \mathrm{mg}\right.$ ). Frac. 3 was rechromatographed on a silica gel column (eluted with $\mathrm{CHCl}_{3}$ and ether) followed by preparative TLC (solvent system, $\mathrm{CHCl}_{3}$ : ether $=1: 2$ ) to yield compound VI (45 $\mathrm{mg}$ ).

The upper layer was concentrated to a syrup under reduced pressure, and chromatographed on a silica gel column $(120 \mathrm{~g})$ using $\mathrm{CHCl}_{3}(800 \mathrm{ml}), 5 \%$ methanol in $\mathrm{CHCl}_{3}(600 \mathrm{ml})$ and $10 \%$ methanol in $\mathrm{CHCl}_{3}\langle 600$ $\mathrm{ml}$ ) as eluents. The fractions eluted with $10 \%$ methanol in $\mathrm{CHCl}_{3}$ were collected and rechromatographed on the silica gel column using $2 \%$ methanol in $\mathrm{CHCl}_{3}$ as an eluent. The fractions containing compound $\mathrm{V}$ were collected and subjected to DCCC. The fractions containing pure compound V (Frac. Nos. 101-108) were combined and concentrated to a syrup. The syrup was dissolved in a small amount of methanol and water was added to afford compound $\mathrm{V}$ as an amorphous powder $(55 \mathrm{mg})$.

Compound I, 1-(2,4,6-Trimethoxyphenyl)-but-trans-2-en-1-one_Colorless plates from ethanol, $\mathrm{mp}$ 84-89 ${ }^{\circ}$. Calcd. for $\mathrm{C}_{13} \mathrm{H}_{16} \mathrm{O}_{4}: 236.1049(\mathrm{M})$, Found: $236.1065\left(\mathrm{M}^{+}\right)$. MS $m / z(\%) ; 236(47), 221(27), 195$ (100). UV $\lambda_{\max }^{\mathrm{MeOH}}(\log \varepsilon): 224(4.29), 302(3.49)$. IR $\nu_{\max }^{\mathrm{KBr}} \mathrm{cm}^{-1}: 3000,2970,2940,2845,1645,1605,1587$, 1497, 1468, 1340, 1277, 1208, 1155, 1125, 970, 807. PMR $(60 \mathrm{MHz}) \delta_{\mathrm{CDCl}_{3}} 1.78(3 \mathrm{H}, \mathrm{d}, J=6 \mathrm{~Hz}), 3.63(6 \mathrm{H}, \mathrm{s})$, $3.70(3 \mathrm{H}, \mathrm{s}), 5.99(2 \mathrm{H}, \mathrm{s}), 6.13(1 \mathrm{H}, \mathrm{d}, J=16 \mathrm{~Hz}), 6.54(1 \mathrm{H}$, d of q, $J=16$ and $6 \mathrm{~Hz}) . \mathrm{CMR}_{\mathrm{CDCl}_{3}} 18.2(\mathrm{q})$, 55.4 (q), 55.8 (q), 90.8 (d), 111.7 (s), 134.3 (d), 145.0 (d), 158.5 (s), 162.2 (s) 194.6 (s).

Compound II, 5,7-Dimethoxy-2-methylchromanone-Colorless needles from a mixture of $n$-hexane and benzene, $\mathrm{mp} 77-79^{\circ}$. Calcd. for $\mathrm{C}_{12} \mathrm{H}_{14} \mathrm{O}_{4}: 222.0892(\mathrm{M})$, Found: $222.0890\left(\mathrm{M}^{+}\right)$. MS $\mathrm{m} / \mathrm{z}(\%): 222$ (71), $180(100), 152(54), 137(44)$. UV $\lambda_{\max }^{\mathrm{MeOH}} \mathrm{nm}(\log \varepsilon): 227(4.31), 283$ (4.31). IR $v_{\max }^{\mathrm{KBr}} \mathrm{cm}^{-1}: 2970,2935$, $2845,1665,1600,1568,1460,1342,1261,1218,1153,1118,799$. PMR $(60 \mathrm{MHz}) \delta_{\mathrm{CDCl}_{3}}: 1.40(3 \mathrm{H}, \mathrm{d}, J=7 \mathrm{~Hz})$, $2.53(2 \mathrm{H}, \mathrm{d}, J=7 \mathrm{~Hz}), 3.74(3 \mathrm{H}, \mathrm{s}), 3.80(3 \mathrm{H}, \mathrm{s}), 4.45(1 \mathrm{H}$, sextet, $J=7 \mathrm{~Hz}), 5.98(2 \mathrm{H}, \mathrm{s})$.

Compound III, 2-Ethyl-5,7-dimethoxychromanone-Colorless needles from a mixture of $n$-hexane and benzene, $\mathrm{mp} 200-202^{\circ}$. Calcd. for $\mathrm{C}_{13} \mathrm{H}_{16} \mathrm{O}_{4}: 236.1049(\mathrm{M})$, Found: $236.1046\left(\mathrm{M}^{+}\right)$. MS $m / z(\%): 236$ (66), $207(22), 180(100)$. UV $\lambda_{\max }^{\mathrm{MeOH}} \mathrm{nm}(\log \varepsilon): 228(4.41), 284(4.41) . \quad$ IR $\nu_{\max }^{\mathrm{KBr}} \mathrm{cm}^{-1}: 2970,1670,1605$, $1573,1468,1268,1215,1205,1155,1115,815$. PMR $(60 \mathrm{MHz}) \delta_{\mathrm{CDC}_{3}}: 1.04(3 \mathrm{H}, \mathrm{t}, J=7 \mathrm{~Hz}), 1.80(2 \mathrm{H}$, quintet, $J=7 \mathrm{~Hz}), 3.82(3 \mathrm{H}, \mathrm{s}), 3.87(3 \mathrm{H}, \mathrm{s}), 4.31(1 \mathrm{H}$, quintet, $J=7 \mathrm{~Hz}), 6.06(2 \mathrm{H}, \mathrm{s}), 2.60(2 \mathrm{H}, \mathrm{d}, J=7 \mathrm{~Hz})$.

Compound IV, 5-Hydroxy-dimethoxy-2-methylchromanone_-Colorless needles from ethanol, $\mathrm{mp}$ $83-86^{\circ}$. Calcd. for $\mathrm{C}_{12} \mathrm{H}_{14} \mathrm{O}_{5}: 238.0841$ (M), Found: $238.0841\left(\mathrm{M}^{+}\right)$. MS $m / z(\%): 238(68), 223(11), 196$ $(100), 178(18)$. UV $\lambda_{\max }^{\mathrm{MeOH}} \mathrm{nm}(\log \varepsilon): 212(4.29), 245(4.09), 288(4.16), 349(3.68)$. IR $v_{\max }^{\mathrm{KBr}} \mathrm{cm}^{-1}: 3200$, $2970,2890,2830,1650,1600,1578,1505,1461,1343,1255,1206,1115,783$. PMR $(60 \mathrm{MHz}) \delta_{\mathrm{CDCl}_{3}}: 1.34$ $(3 \mathrm{H}, \mathrm{d}, J=7 \mathrm{~Hz}), 2.48(2 \mathrm{H}, \mathrm{d}, J=7 \mathrm{~Hz}), 3.73(3 \mathrm{H}, \mathrm{s}), 3.81(3 \mathrm{H}, \mathrm{s}), 4.49(1 \mathrm{H}$, sextet, $J=7 \mathrm{~Hz}), 6.06(1 \mathrm{H}, \mathrm{s})$.

Compound V, 3- $\beta$-D-Allosyloxy-1-(2-hydroxy-4,6-dimethoxyphenyl)-butan-1-one_-Colorless amorphous powder from a mixture of methanol and water, $[\alpha]_{\mathrm{D}}^{25}-25^{\circ}(c=2.8, \mathrm{MeOH})$. MS $m / z(\%): 240(1), 222(13)$, $207(100), 181(23)$. UV $\lambda_{\max }^{\mathrm{MeOH}} 291 \mathrm{~nm}(\log \varepsilon 4.28), \lambda_{\max }^{\mathrm{MeOH}+\mathrm{A} 1 \mathrm{Cl}} \mathrm{s} 310 \mathrm{~nm}(\log \varepsilon 4.43) . \quad \mathrm{IR} \nu_{\max }^{\mathrm{KBr}} \mathrm{cm}^{-1}: 3400$, $2930,1620,1590,1220,1160,1090,1030$. PMR $(60 \mathrm{MHz}) \delta_{\text {pyr. }_{*}-d_{s}}: 1.44(3 \mathrm{H}, \mathrm{d}, J=7 \mathrm{~Hz}), 3.07(1 \mathrm{H}, \mathrm{d}$ of d, $J=16$ and $7 \mathrm{~Hz}), 3.70(6 \mathrm{H}, \mathrm{s}), 3.5-5.0(8 \mathrm{H}), 5.39(1 \mathrm{H}, \mathrm{d}, J=7 \mathrm{~Hz}), 5.99(1 \mathrm{H}, \mathrm{d}, J=2 \mathrm{~Hz}), 6.23(1 \mathrm{H}, \mathrm{d}$, $J=2 \mathrm{~Hz}$ ).

Compound VI, Ryomenin —Colorless needles from a mixture of $n$-hexane and benzene, $\mathrm{mp} 204-207^{\circ}$, $[\alpha]_{\mathrm{D}}^{25}-214^{\circ}(c=0.14, \mathrm{MeOH})$. Calcd. for $\mathrm{C}_{15} \mathrm{H}_{18} \mathrm{O}_{3}: 246.1256(\mathrm{M})$, Found: $246.1263\left(\mathrm{M}^{+}\right)$. MS $m / z(\%)$ : $246(100), 231(47), 213(15), 201(41)$. UV $\lambda_{\max }^{\mathrm{MeOH}} \mathrm{nm}(\log \varepsilon): 211(4.51), 252(3.98), 310(3.58) . \quad \mathrm{IR} v_{\max }^{\mathrm{KBr}} \mathrm{cm}^{-1}$ : $3500,2925,2870,1675,1610,1428,1195,725$. PMR (100 MHz) $\delta_{\text {py r. }-d_{s}}: 1.23(3 \mathrm{H}, \mathrm{d}, J=7 \mathrm{~Hz}), 1.68(3 \mathrm{H}$,

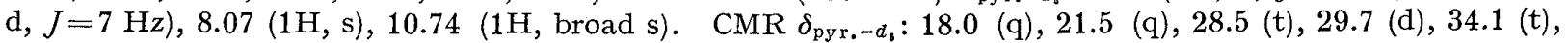


41.8 (t), 44.7 (d), 49.7 (d), 115.2 (d), 126.0 (s), 131.4 (s), 135.9 (s), 148.0 (s), 155.3 (s), 169.8 (s).

Compound IV Methyl Ether (VII)_An excess of diazomethane in ether was added to a solution of compound IV $(5 \mathrm{mg})$ in ether $(3 \mathrm{ml})$, and the solution was allowed to stand overnight. The solution was concentrated and the residue was purified by recrystallization from $n$-hexane to give the methyl ether (VII) as colorless needles. IR $v_{\max }^{\mathrm{KBr}} \mathrm{cm}^{-1}: 1675,1600,1575,1500,1355,1275,1125$.

Acid Hydrolysis of Compound V-Compound V $(30 \mathrm{mg})$ was dissolved in $5 \% \mathrm{HCl}(5 \mathrm{ml})$ and the solution was heated on a water bath $\left(90^{\circ}\right)$ for $3 \mathrm{hr}$. The reaction mixture was extracted with ethyl acetate. The ethyl acetate layer was washed with water, then dried, and evaporated to dryness. The residue was purified by preparative TLC using $\mathrm{CHCl}_{3}$-ether $(2: 1)$. Recrystallization from $n$-hexane-benzene afforded colorless needles $(6 \mathrm{mg}), \mathrm{mp} 76-78^{\circ}$, which were identical with compound II (IR, TLC and mixed fusion). The aqueous layer was concentrated under reduced pressure to yield a syrup $(9 \mathrm{mg}),[x]_{\mathrm{D}}^{22}+12^{\circ}\left(c=0.45, \mathrm{H}_{2} \mathrm{O}\right)$. The syrup was trimethylsilylated with hexamethyldisilazane and trimethylchlorosilane in pyridine. Trimethylsilylated D-allose was detected in the solution by GLC: column temp. $165^{\circ}$, carrier gas $\mathrm{N}_{2}\left(1.1 \mathrm{~kg} / \mathrm{cm}^{2}\right)$, $t_{\mathrm{R}}(\mathrm{min}) 13.0$ and 13.8 , in agreement with those of an authentic sample.

3-Hydroxy-1-(2,4,6-trimethoxyphenyl)-butan-1-one (IX)_-A solution of compound I (100 mg) in $\mathrm{MeOH}(3 \mathrm{ml})$ was treated with $10 \% \mathrm{H}_{2} \mathrm{SO}_{4}(3 \mathrm{ml})$, and the mixture was refluxed for $5 \mathrm{hr}$. The reaction mixture was then diluted with water $(20 \mathrm{ml})$ and extracted with ethyl acetate. The ethyl acetate layer was washed with water, then dried, and evaporated to dryness. The residue was purified by preparative TLC, using $\mathrm{CHCl}_{3}$-ether (1:1), to give 3-hydroxy-1-(2,4,6-trimethoxyphenyl)-butan-1-one (IX, $24 \mathrm{mg}$ ), together with 3-methoxy-1-(2,4,6-trimethoxyphenyl)-butan-1-one (XIV, $33 \mathrm{mg})$. IX: Colorless syrup. UV $\lambda_{\max }^{\mathrm{MeOH}} 276 \mathrm{~nm}(\log \varepsilon 3.76)$, unchanged on addition of $\mathrm{AlCl}_{3}$. PMR $(60 \mathrm{MHz}) \delta_{\mathrm{CD}_{3} \mathrm{OD}}: 1.18(3 \mathrm{H}, \mathrm{d}, J=$ $7 \mathrm{~Hz}), 2.83(2 \mathrm{H}, \mathrm{d}, J=7 \mathrm{~Hz}), 3.71(6 \mathrm{H}, \mathrm{s}), 3.75(3 \mathrm{H}, \mathrm{s}), 4.12(1 \mathrm{H}$, sextet, $J=7 \mathrm{~Hz}), 6.10(2 \mathrm{H}, \mathrm{s})$. XIV: Colorless needles from ethanol, mp 101-103․ MS $m / z(\%): 268(4), 253(2), 236(2), 195(100)$. UV $\lambda_{\max }^{\mathrm{MeOH}}$ $279 \mathrm{~nm}(\log \varepsilon 3.79)$. PMR $(60 \mathrm{MHz}) \delta_{\mathrm{CDCl}_{\mathrm{a}}}: 1.10(3 \mathrm{H}, \mathrm{d}, J=6 \mathrm{~Hz}), 2.61(1 \mathrm{H}, \mathrm{d}$ of $\mathrm{d}, J=16$ and $6 \mathrm{~Hz}), 3.02$ $(1 \mathrm{H}$, d of d, $J=16$ and $6 \mathrm{~Hz}), 3.18(3 \mathrm{H}, \mathrm{s}), 3.60(1 \mathrm{H}, \mathrm{m}), 3.66(6 \mathrm{H}, \mathrm{s}), 3.70(3 \mathrm{H}, \mathrm{s}), 5.98(2 \mathrm{H}, \mathrm{s})$.

Ryomenin Methyl Ester (XIII)__ An excess of diazomethane in ether was added to a solution of ryomenin $(10 \mathrm{mg})$ in ether $(5 \mathrm{ml})$, and the solution was allowed to stand overnight. The solvent was evaporated off and the residue was recrystallized from methanol to give the methyl ester (XIII) as prisms, $\mathrm{mp} 163-165^{\circ}$, $[\alpha]_{\mathrm{D}}^{25}-198^{\circ}(c=0.28, \mathrm{MeOH})$. Calcd. for $\mathrm{C}_{16} \mathrm{H}_{20} \mathrm{O}_{3}: 260.1413(\mathrm{M})$, Found: $260.1409\left(\mathrm{M}^{+}\right)$. MS $m / z(\%): 260$ $(100 \%), 245(74), 227(17), 213(44), 201(56) . \quad$ IR $v_{\max }^{\mathrm{KBr}} \mathrm{cm}^{-1}: 3420,3000,2950,2920,2850,1685,1605,1435$, 780 .

Acknowledgement We are grateful to Dr. S. Natori, National Institute of Hygienic Sciences of Japan, for his valuable advice concerning the stereochemistry of compounds II, III and IV. 